\title{
A VULNERABILIDADE DAS MULHERES ENCARCERADAS E A JUSTIÇA SOCIAL: O Importante Papel da Educação na Efetividade no Processo de Ressocialização
}

http://dx.doi.org/10.21527/2176-6622.2019.51.61-77

Recebido em: 13/4/2019

Modificações requeridas em: 28/4/2019

Aceito em: 21/5/2019

\section{Dirceu Pereira Siqueira}

Coordenador e professor permanente do Programa de Mestrado em Direito do Centro Universitário Cesumar (UniCesumar). Pós-Doutorado em Direito pela Faculdade de Direito da Universidade de Coimbra (Portugal). Doutorado e Mestrado em Direito Constitucional pela Instituição Toledo de Ensino - ITE/Bauru. Especializacão em Direito Civil e Processual Civil pelo Centro Universitário de Rio Preto. Pesquisador Bolsista Modalidade Produtividade em Pesquisa para Doutor - PPD - Instituto Cesumar de Ciência, Tecnologia e Inovação (Iceti). Professor nos cursos de Graduação em Direito da Universidade de Araraquara (Uniara), do Centro Universitário Unifafibe (Unifafibe) e do Centro Universitário da Fundação Educacional de Barretos (Unifeb). Professor convidado do Programa de Mestrado em "Gestão Estratégica de Empresas - Master Of Science in Administrative Studies (MSAS)". Consultor jurídico. Parecerista. Advogado. dpsiqueira@uol.com.br

\section{Sabrina Medina Andrecioli}

Mestranda no Programa de Pós-Graduação em Ciências Jurídicas do Centro Universitário Cesumar de Maringá (Unicesumar). Pós-Graduação em Direito Aplicado pela Escola da Magistratura do Paraná - Emap. Advogada.sah_andri@hotmail.com

\section{RESUMO}

Diante de um cenário de enormes violações de direitos que a população carcerária feminina vivencia, verifica-se a real importância de se tratar da temática e dos direitos dessa população. Este trabalho, portanto, tem por objetivo retratar as violações das mulheres em situação de cárcere a partir do princípio da dignidade da pessoa humana, como valor fundante de todo o sistema jurídico-social brasileiro. Assim, procurou-se analisar o conceito de vulnerabilidade social, minorias e grupos vulneráveis, qualificando a mulher encarcerada como grupo vulnerável, precisamente no sentindo de dar condição de igualdade em relação aos demais indivíduos da sociedade. Para a efetiva concretização dos direitos sociais, por meio das ações positivas por parte do Estado e sociedade que promovam a dignidade da pessoa humana e a garantia do mínimo vital, deve-se se passar pela adequada consideração do âmbito da norma, isto é, de seu suporte fático concreto e abstrato. Este trabalho, entretanto, tem por objetivo retratar as violações das mulheres presas, os desafios enfrentados pelo Estado na efetivação dos direitos sociais e a relevância do direito à educação para a factual ressocialização. Empregou-se, para tanto, o método dedutivo de abordagem com o intuito de levantamento de hipóteses reflexivas sobre a temática do cárcere brasileiro e seus problemas, especificamente o encarceramento feminino e as violações de direitos sofridas pelas mulheres. Quanto aos métodos de investigação, utiliza-se o bibliográfico, a partir de uma revisão de literatura de obras, artigos de periódicos e documentos eletrônicos oficiais.

Palavras-chave: Direitos sociais. Educação. Justiça social. Mulheres presas. Vulnerabilidade.

THE VULNERABILITY OF JAILED WOMEN AND SOCIAL JUSTICE:

\section{THE IMPORTANT ROLE OF EDUCATION IN EFFECTIVENESS IN THE RESSOCIALIZATION PROCESS}

\section{ABSTRACT}

Faced with a scenario of enormous violations of rights that the female prison population experiences is that the real importance of dealing with the issue and the rights of this population is verified. Therefore, this work aims to portray the violations of women in prison, based on the principle of the dignity of the human person as a founding value of the entire Brazilian legal-social system. Thus, it was worried to analyze the concept of social vulnerability, minorities and vulnerable groups, qualifying the imprisoned woman as a vulnerable group, precisely in the sense of giving equality status to other individuals in society. For the effective realization of social rights, through positive actions by the State and society that promote the dignity of the human person and guarantee the vital minimum, one must take the proper consideration of the scope of the norm, that is, of its support concrete and abstract. Therefore, this paper aims to portray the violations of women prisoners, the challenges faced by the state in the implementation of social rights and relevance of the right to education for factual re-socialization. The deductive method of approach was used to investigate the hypotheses about the Brazilian prison and its problems, specifically the female incarceration and the violations of rights suffered by women. And, how many to the methods of investigation, the bibliographical one is used from a review of literature of works, articles of periodicals and official electronic documents.

Keywords: Social rights. Education. Social justice. Women prey. Vulnerability.

\section{SUMÁRIO}

1 Introdução. 2 Da vulnerabilidade social e igualdade. 2.1 Das minorias e grupos vulneráveis. 3 Dos desafios enfrentados pelo Estado na efetivação dos direitos sociais. 4 Da ressocialização da mulher presa e a efetiva justiça social. 4.1 Da justiça social. 4.2 Da ressocialização da mulher presa e os direitos sociais à educação. 5 Considerações finais. 6 Referências. 


\section{INTRODUÇÃO}

Ser mulher parece ser também uma condenação a um "lugar", que é o de inferioridade, do menosprezo e da irracionalidade. Este é o lugar precípuo que a construção social de gênero destina às mulheres. Não é necessário estar em uma prisão para saber disto, mas é na prisão que todos esses estereótipos sobre o feminino afloram como uma ferida purulenta e fétida, sem tratamento que possa amenizar a dor de ser o que se é: uma mulher criminosa.

O crescimento do encarceramento feminino é um fenômeno que tem se acentuado nos últimos anos. Os dados oficiais trazidos pelo Infopen ${ }^{1}$ demonstram que o número de pessoas presas cresceu $707 \%$ em relação ao total registrado no início da década de 90. Apesar do grande aumento do percentual da população feminina no sistema prisional brasileiro, ainda se verifica um número de mulheres presas bastante inferior ao de homens. Fato utilizado para justificar a secundarização das necessidades específicas e para a quase inexistência de política penitenciária que atenda o gênero feminino.

Os presídios afiguram-se como verdadeiros depósitos humanos e palcos das maiores violações aos direitos fundamentais do homem. Na sentença penal não somente há o cerceamento da liberdade do cidadão, mas de outros direitos essenciais que parecem invisíveis para o Estado, como a educação, a honra, a privacidade, a liberdade sexual e a assistência jurídica. $O$ afastamento entre a vontade da lei e a realidade do sistema carcerário nacional é acentuado e decorre da falta de vontade política do Estado em tutelar uma minoria impopular. A começar pelo princípio da dignidade da pessoa humana, consagrado na Constituição Federal de 1988 (artigo 1인), é demarcado um campo de padrão mínimo na esfera dos direitos sociais, e isso evidencia que a falta de condições materiais mínimas ao homem retira da pessoa o seu desenvolvimento físico e psíquico, gerando a injustiça.

Com relação às mulheres encarceradas, objeto de estudo deste trabalho, verifica-se diversos problemas e questões delicadas do cárcere feminino, como a situação da maternidade no cárcere, a gravidez, a extensão dos efeitos do cárcere aos filhos, a manutenção de vínculos familiares e afetivos, a efetivação do direito à visita íntima, a concessão de prisão domiciliar diante de instalações improvisadas nos presídios destinados a abrigar mulheres, dentre outros problemas institucionais.

O cenário do encarceramento feminino brasileiro evidencia, portanto, ausência de tutela do Estado com relação a esse grupo vulnerável da população e o desrespeito com os direitos fundamentais e de personalidade dos apenados com fins de res(socialização). A vulnerabilidade deste grupo de indivíduos reflete a desigualdade existente, a qual deveria ser tratada com a importância devida.

Utiliza-se o método de abordagem dedutivo, partindo de teorias gerais para a ocorrência de fenômenos particulares na busca do derradeiro objetivo representado na identificação sujeito-objeto do estudo e seus direitos, sendo realizada uma análise reflexiva. Aliado à abordagem dedutiva, será utilizado o método dialético, sob o ponto de vista hegeliano, na tentativa de apresentar argumentos e contra-argumentos sólidos sobre a hipótese inicialmente levantada, a fim de apurar suas possíveis contradições. Já como método de procedimento, utiliza-se o estatístico e o funcional, consistindo em analisar o todo do ponto de vista da função de suas unidades. Por fim, quanto aos métodos de investigação, emprega-se o bibliográfico e o documental, realizado por meio de consulta de obras, artigos de periódicos e documentos eletrônicos.

Para tanto, o estudo foi dividido em três seções. Na primeira, analisar-se-á o conceito de vulnerabilidade social e igualdade, demonstrando a importância destas questões introdutórias para se captar a essência da fragilidade social dos grupos vulneráveis e minorias sociais, dando enfoque à vulnerabilidade da mulher em situação de cárcere. Assim, far-se-á um breve exame dos conceitos de minorias e grupos vulneráveis, estabelecendo os pontos em comum, bem como os pontos de divergências, buscando elucidar a importância da distinção entre eles para a adequada concretização dos direitos fundamentais. A segunda seção vai se preocupar

\footnotetext{
Infopen consiste em um sistema de informações estatísticas do sistema penitenciário brasileiro, atualizado pelos gestores dos estabelecimentos desde 2004 e sintetizando informações sobre os estabelecimentos penais e a população prisional. Disponível em: http://depen. gov.br/DEPEN/depen/sisdepen/infopen. Acesso em: 14 fev. 2019.
} 
em analisar os desafios enfrentados pelo Estado na efetivação dos direitos sociais, quando se enfatizará que a eficiência dos direitos sociais depende diretamente da correta compreensão dos seus destinatários, com suas respectivas peculiaridades, e dos fatores que geram suas vulnerabilidades diante do caso concreto.

Por fim, a terceira parte investigará o fenômeno ressocialização da mulher presa para a efetiva justiça social, trazendo a relevância do direito à educação no atual cenário jurídico-social brasileiro e as necessidades de perspectivas diferenciadas no tratamento da temática. Seguindo essa visão, será enfatizada a necessidade da imposição de políticas públicas destinadas a melhorar a educação de jovens do sexo feminino, tendo em vista a notoriedade dos reflexos diretos que a precariedade da educação do Estado brasileiro gera em outras áreas, como a da saúde, índices de mortalidade e, principalmente, no sistema carcerário.

\section{DA VULNERABILIDADE SOCIAL E IGUALDADE}

Há uma impossibilidade de subsistência dos direitos fundamentais, quando a igualdade é cerceada pela vulnerabilidade que ataca determinados grupos ou pessoas. Nesse sentido, a igualdade é uma ideia a ser construída, ou seja, que precisa ser obtida por meio de reivindicações e conquistas, especialmente porque a desigualdade tem potencial de prejudicar toda a sociedade (ROTHENBURG, 2008, p. 78-79).

Em termos jurídicos, a igualdade expressa-se sob a forma de norma da espécie princípio; e como princípio é considerado parte da estrutura do sistema constitucional global. Assim, Canotilho e Moreira (2007, p. 3) aduzem:

O princípio da igualdade é um dos princípios estruturantes do sistema constitucional global, conjugando dialeticamente as dimensões liberais, democráticas e sociais inerentes ao conceito de Estado de direito democrático e social.

Exatamente por ser um princípio jurídico, a igualdade tem sua aplicação condicionada por outras normas. Conforme Alexy (1993, p. 86), os princípios podem ser aplicados em maior ou menor medida, sendo "mandatos de optimización" (ordens de confiança), isto é, caracterizam-se pelo fato de poderem ser cumpridos em diferentes graus e na medida devida de seu cumprimento, dependendo de possibilidades jurídicas e reais.

O princípio fundamental da igualdade deve-se também se expressar em regras (normas mais específicas), que caracterizam concretizações da igualdade em diversos níveis (ROTHENBURG, 2008, p. 80). Vislumbra-se, assim, a importância desse princípio em virtude de seu valor central no direito contemporâneo, e por estar presente desde as primeiras declarações de direitos. Para Comparato (2014, p. 62), o artigo I da Declaração da Independência Americana é o registro de nascimento dos Direitos Humanos na história, vindo a consolidar a ideia de igualdade entre os homens, também presente na Declaração do Homem e do Cidadão de 1789.

Após as duas grandes guerras mundiais tornou-se necessário o reconhecimento da Dignidade da Pessoa Humana como uma conquista de razão ético-jurídica. A Declaração Universal dos Direitos Humanos, de 1948, tinha, assim, requisito único para a titularidade de direitos e a própria condição humana; a dignidade humana passa a ser incorporada por todos os outros tratados e declarações de direitos humanos que passaram a integrar o Direito Internacional (PIOVESAN, 2013, p. 210).

A dignidade da pessoa humana desempenha um grande papel nessa teoria jurídica repaginada, no qual a interpretação da norma é marcantemente motivada por valores éticos e fatos sociais. Nessa esteira, diante da reconstrução do mundo moralmente devastado pelo totalitarismo e pelo genocídio, Luís Roberto Barroso (2013, p. 18-19) aduz:

[...] A dignidade humana foi incorporada ao discurso político dos vitoriosos como uma das bases para uma longa e aguardada era de paz, democracia e proteção dos direitos humanos. A dignidade humana foi então importada para o discurso jurídico devido a dois fatores principais. O primeiro deles foi a inclusão em diferentes tratados e documentos internacionais, bem como em diversas constituições nacionais, de referências textuais à dignidade humana. $\mathrm{O}$ segundo fator corresponde a um fenômeno mais sutil, que se tornou mais visível com o passar do tempo: a ascensão de uma cultura jurídica, pós-positivista, que reaproximou o direito da moral e da filosofia política, atenuando a separação radical imposta pelo positivismo pré-Segunda Guerra. 


\section{Debate}

A Declaração Universal dos Direitos Humanos de 1948 objetivou delinear uma ordem pública fundada no respeito à dignidade humana, e, ao consagrar valores básicos universais, consagrou a dignidade da pessoa. Deste modo, a dignidade humana tornou-se o valor fundante do sistema dos direitos fundamentais e se converteu no patrimônio jurídico-moral da pessoa humana estampada nos direitos subjetivos incorporados e assegurados pelo sistema constitucional. Foi a partir desse momento histórico, iniciando-se pela própria Declaração de 1948, que o princípio da igualdade passou a constar no sistema internacional de proteção dos direitos humanos.

Desta feita, a Constituição Brasileira de 1988 é um espelho da metamorfose paradigmática da lente ex parte principis para a ex parte populi, ou seja, não é mais sob a perspectiva do Estado que se afirma o direito, e sim sob a perspectiva dos direitos que se afirma o Estado (PIOVESAN, 2013, p. 96). A dignidade da pessoa humana é a norma irradiadora que instrui o constitucionalismo contemporâneo, princípio em que todos os ângulos éticos da personalidade se acham consubstanciados (BONAVIDES, 2001, p. 233).

Dentro do cenário atual da afirmação da dignidade humana, tendo a igualdade como um de seus corolários, o que se levanta é que não basta simplesmente aduzir que "todos são iguais perante a lei, sem distinção de qualquer natureza [...]", conforme leciona o artigo 5 da Constituição brasileira, e torna-se essencial, também, trabalhar com soluções para casos concretos.

Os indivíduos são essencialmente diferentes, devendo ser protegidos na medida de suas diferenças. 0 conceito de igualdade de Boaventura Souza Santos (2003, p. 106) enquadra perfeitamente a importância de se entender a igualdade por intermédio da luz da diferença. Segundo ele, "[...] temos o direito a ser iguais quando a nossa diferença nos inferioriza; e temos o direito a ser diferentes quando a nossa igualdade nos descaracteriza".

O princípio da igualdade implica proibição de discriminações indevidas. Nesse sentido, Rothenburg (2008, p. 82) trabalha sobre a igualdade formal e material:

O combate à discriminação, como dimensão "negativa" (de viés repressor) da igualdade, pode assumir formulações mais específicas, com vistas à proteção de determinadas pessoas ou grupos em situação de vulnerabilidade. Assim, para além da igualdade formal, normas jurídicas de proibição podem traduzir o anseio por igualdade material.

Importante, então, se faz a distinção entre igualdade material e formal. Segundo Miguel Carbonell (2003, p. 13), a igualdade material exige dos poderes públicos atos de remoção dos obstáculos que impedem a efetivação de uma igualdade de fato, inclusive podendo demandar o estabelecimento de medidas de discriminação inversa. Já a igualdade formal é dirigida principalmente aos legisladores. É aquela constante nas declarações e constituições que afirmam que todos são iguais perante a lei; assim, a igualdade formal, por si só, passava uma ideia de proteção geral e abstrata, revelando ser insuficiente (REZEC NETO; BORCAT, 2015, p. 107).

Verifica-se em Sarlet (2012, p. 78) a existência de duas dimensões da igualdade: a objetiva e a subjetiva. A objetiva é comtemplada como valor e princípio fundamental do direito constitucional, sendo base do Estado Democrático e Social de Direito, ensejando o dever do Estado de proteger as pessoas e combater os atos discriminatórios. Já a igualdade subjetiva seria, basicamente, um ponto de defesa e um aspecto prestacional (negativo e positivo).

Quanto aos destinatários do direito da igualdade, o mesmo autor assevera que seriam os órgãos estatais, em primeira linha, vinculando todos os órgãos, funções e ações estatais para a plena aplicabilidade. 0 direito à igualdade abrange toda a ordem privada, mediada pelo legislador na sua projeção e nas suas cláusulas especiais (SARLET, 2012, p. 80-81).

É nesse espaço que as minorias e grupos vulneráveis passam a ser vistas nas especificidades de sua condição social; as diferenças devem ser respeitadas, passando do nicho da igualdade formal para a material. Desse modo, quando a igualdade é violada, a consequência natural é considerar o surgimento de uma desigualdade. A desigualdade, assim, seria a origem da vulnerabilidade social de grupos ou diversas pessoas. Miriam Abramovay et al. (2002, p. 29) assevera sobre a consequência negativa originada da relação estabelecida entre disponibilidade dos recursos materiais e/ou simbólicos dos indivíduos ou grupos, e o acesso à estrutura de oportunidades sociais, econômicas e culturais provenientes do Estado, mercado e sociedade. 
Sintetizando, a vulnerabilidade fundamenta-se em três elementos básicos para sua caracterização: os recursos materiais ou simbólicos, as estruturas de oportunidades que são oferecidas pelo Estado, sociedade e mercado e as estratégias de uso de ativos.

Nesse sentido, é mais vulnerável um grupo ou indivíduo que, por diferentes razões, tem sua capacidade de acessar direitos ou de se defender reduzida. Segundo Castro et al. (2002, p. 30), vulnerabilidade se traduz como:

[...] situação em que o conjunto de características, recursos e habilidades inerentes a um dado grupo social se revelam insuficientes, inadequados ou difíceis para lidar com o sistema de oportunidades oferecido pela sociedade, de forma a ascender a maiores níveis de bem-estar ou diminuir probabilidades de deterioração das condições de vida de determinados atores sociais.

Isto posto, políticas públicas como ações afirmativas neutralizam os efeitos da discriminação e também apresentam um conteúdo de transformação social. As desigualdades de gênero determinam a condição de vulnerabilidade das mulheres presas, pois estão sujeitas a vulnerabilidades e riscos que incluem a violação de direitos humanos e sociais, tais como o direito à vida, à saúde e à educação, conforme será abordado mais detalhadamente nos próximos tópicos.

\subsection{Das minorias e grupos vulneráveis}

Feita a análise, mesmo que breve, sobre o conceito de igualdade e da ideia de vulnerabilidade, passase a distinguir minorias de grupos vulneráveis tendo em vista que a correta compreensão desses conceitos é de essencial importância para o estudo dos direitos sociais e, consequentemente, na execução de políticas públicas eficientes e adequadas a cada destinatário, concernentes às suas características próprias. Assim, a diferenciação dos conceitos é essencial para que as ações afirmativas efetivamente propostas e executadas atinjam seus reais objetivos.

Destaca-se, primeiramente, a importância da análise dos conceitos de grupos vulneráveis e minorias, na medida em que em diversos estudos essas terminologias têm sido empregadas, muitas vezes, como sinônimos, não havendo muita precisão (ANJOS FILHO, 2010, p. 342).

Conforme o exposto anteriormente, a não exclusão das minorias e grupos vulneráveis vai depender que exista mais do que a igualdade formal, posto que esta não impreterivelmente indica uma aplicação efetiva do princípio da igualdade, uma vez que "[...] para tal concretização será necessária uma atividade jurídica que contemple uma verdadeira interpretação dos dispositivos legais de modo a atender as minorias" (SIQUEIRA; MINHOTO, 2012, p. 14).

No âmbito internacional, as Nações Unidas, no ano de 1950, por meio da Subcomissão de Prevenção de Discriminação e de Proteção de Minorias, sugeriu o seguinte conceito de minorias:

I - o termo minoria inclui, dentro do conjunto da população, apenas aqueles grupos não dominantes, que possuem e desejam preservar tradições ou características étnicas, religiosas ou lingüísticas estáveis, marcadamente distintas daquelas do resto da população; II - tais minorias devem propriamente incluir um número de pessoas suficiente em si mesmo para preservar tais tradições e características e III - tais minorias devem ser leais ao Estado dos quais sejam nacionais.

Já o Pacto Internacional dos Direitos Civis e Políticos, ${ }^{2}$ de 1966 , elenca algumas dessas características no seu artigo 27. ${ }^{3}$ Da mesma forma, a Organização das Nações Unidas define que:

A descrição mais habitualmente utilizada de uma minoria num dado Estado pode ser resumida como um grupo não dominante de indivíduos que partilham certas características nacionais, étnicas, religiosas ou linguísticas, diferentes das características da maioria da população (NAÇÕES UNIDAS, 2008, p. 18).

\footnotetext{
2 Ratificado pelo Brasil em 1992 por meio do Decreto no 592, de 6 de julho de 1992. Disponível em: http://www.refugiados.net/cid_virtual_bkup/asilo2/2pidcp.html. Acesso em: 10 jun. 2018.

3 Artigo 27 - Nos Estados em que haja minorias étnicas, religiosas ou linguísticas, as pessoas pertencentes a essas minorias não poderão ser privadas do direito de ter, conjuntamente com outros membros de seu grupo, sua própria vida cultural, de professar e praticar sua própria religião e usar sua própria língua.
} 
Como se pode notar, a identificação das minorias não possui um conceito universal definido, e a ONU não institui um conceito fechado. Segundo Robério Nunes Anjos Filho (2010, p. 351), podem, normalmente, ser apontados quatro elementos caracterizadores das minorias: o diferenciador, o quantitativo, o de nacionalidade e o de não dominância, agregando-se, ainda, um outro elemento de natureza subjetiva - o da solidariedade.

O primeiro elemento - o diferenciador - exige a presença, de forma estável, em cada membro do grupo de uma "determinada característica, que o distinga do restante da população", sendo ainda necessária a presença dos demais elementos para caracterizar o grupo minoritário (ANJOS FILHO, 2010, p. 351). Já com relação ao segundo elemento - o quantitativo -, Anjos Filho (2010, p. 352) entende que essa questão quantitativa revela a concepção de que "um grupo numericamente majoritário em uma sociedade não pode ser considerado minoria".

Quanto ao critério numérico, importa mencionar o entendimento de Lopes (2006, p. 55), que partilha que existem determinadas minorias que são maiorias numéricas; o exemplo utilizado para elucidar é o tempo do Apartheid na África do Sul. O critério mais adequado para a autora seria o da exclusão social e a falta de participação nas decisões políticas. Propõe, assim, que "[...] todo grupo humano, cujos membros tenham direitos limitados ou negados apenas pelo fato de pertencerem a esse grupo, deve ser considerado um grupo minoritário" (LOPES, 2006, p. 55-56).

O outro elemento caracterizador das minorias seria o da nacionalidade. A tendência atual é de reconhecer a existência de obrigações dos Estado para a minoria presente nos limites territoriais, independente de as pessoas serem nacionais ou não (ANJOS FILHO, 2010, p. 353).

Neste viés, importa mencionar J. J. G. Canotilho (1993), que, se referindo ao atual modelo do Estado Democrático de Direito, aduz:

A democracia tem como suporte ineliminável o princípio majoritário, mas isso não significa qualquer "absolutismo da maioria" e, muito menos, o domínio da maioria. O direito da maioria é sempre um direito em concorrência com o direito das minorias com o conseqüente reconhecimento de estas se poderem tornar maiorias (p. 456).

Apesar da não dominância dificultar a elaboração de políticas públicas de reconhecimento ou de identidade, este não pode ser um obstáculo para a sua consecução, dado que o elemento norteador dos atos do Estado é o princípio da dignidade da pessoa humana, indissociável da igualdade.

Por fim, o elemento subjetivo da solidariedade, segundo Anjos Filho (2010, p. 354), refere-se à vontade dos indivíduos em manter as características que os distinguem do restante da sociedade. Em síntese, a partir do reconhecimento do grupo minoritário, o sujeito irá simetricamente necessitar de um tratamento diferenciado para garantir o seu enquadramento à sociedade.

Embora grupos minoritários e vulneráveis apresentem semelhanças (como a incidência de vulnerabilidade e o fato de não serem grupos dominantes), possuem elementos distintivos que não podem ser desconsiderados pelo intérprete e aplicador da norma, sob pena de gerar uma desigualdade, com grande perda normativa do texto dos direitos sociais fundamentais.

Assim, a discussão em torno da necessária distinção entre minoria e grupos vulneráveis tem espaço crescente na sociedade, principalmente no que diz respeito a aspectos jurídicos dos termos (SIQUEIRA, 2013, p. 188). Nessa esteira, Anjos Filho (2010, p. 356) denota a existência desta distinção, podendo se falar em grupos de vulneráveis lato sensu e grupos de vulneráveis stricto sensu; o primeiro constitui gênero ao qual pertencem, de acordo com o contexto do Estado, "pessoas portadoras de necessidades especiais físicas ou mentais, idosos, mulheres, favelados, crianças, minorias étnicas, religiosas e linguísticas, índios, descendentes de quilombos, ribeirinhos, trabalhadores rurais, sem-terra, dentre outros".

As minorias se enquadram na ideia de grupos vulneráveis em sentido amplo, mas não no conceito em sentido estrito. O autor fundamenta na E/CN.4/Sub.2/1993/34, do Conselho Econômico e Social das Nações Unidas, que o parágrafo 31 afirma existir "minorias" e "situação minoritária" (ANJOS FILHO, 2010, p. 356). Neste diapasão, existem três elementos diferenciadores básicos entre minorias e grupos vulneráveis, que seriam: o critério numérico, o diferenciador e, por último, o da solidariedade. 
O primeiro critério distingue a minoria como grupo numericamente inferior ao restante da população, e o grupo de vulneráveis, em sentido estrito, pode ser numericamente majoritário. Já o diferenciador refere-se aos traços étnicos, religiosos e linguísticos, ${ }^{4}$ ou seja, o ponto principal é o elemento cultural, pois as minorias possuem um liame que imprime uma identidade cultural ao grupo (ANJOS FILHO, 2010, p. 360). Por fim, o critério da solidariedade refere-se ao desejo de manutenção dos traços diferenciadores; essa exigência não se faz nos grupos vulneráveis em sentido estrito (SIQUEIRA, 2013, p. 190).

O que se extrai de todo o exposto é que a condição de vulnerabilidade está atrelada à identificação de carências discriminadoras, sejam elas pertinentes às minorias ou aos grupos vulneráveis propriamente ditos (CAYRES; CIDADE, 2015, p. 174).

No que se refere à proteção das minorias no âmbito da Constituição Federal de 1988, o artigo 3o preconiza os objetivos fundamentais da República Federativa, ${ }^{5}$ e se identifica a erradicação das desigualdades sociais como base do Estado democrático de direito, o que implica reconhecer respeito e tratamento materialmente igual à todas as pessoas no que concerne à dignidade, com respeito, assim, à manutenção das características das minorias, por intermédio do desenvolvimento da tolerância e da solidariedade. Além disso, a Constituição é permeada de outros institutos que reforçam os objetivos gerais da República; em destaque seriam os próprios direitos fundamentais propriamente ditos (artigos 5 e 6ㅇ). É necessário, portanto, que o Estado promova uma efetiva proteção das minorias, levando em conta suas especificidades, com observância as suas especiais vulnerabilidades de forma a assegurar-lhes o direito à vida digna. Ressalta-se o enquadramento das mulheres em situação de cárcere no conceito de grupo vulnerável, devendo os direitos subjetivos deste grupo serem observados, tendo em vista constituírem direitos fundamentais e gozarem, portanto, de universalidade, irrenunciabilidade e historicidade, demandando medidas redutoras de desigualdade.

Ao exercer concretamente a punibilidade, o Estado tem cerceado não somente a liberdade do cidadão/cidadã, mas também outros direitos fundamentais não abrangidos pela sentença: honra; privacidade; intimidade; liberdade sexual; saúde; educação; assistência jurídica; alimentação; higiene pessoal. Estes são elementos que parecem invisíveis ao Estado, pois vivencia-se um sistema longe de servir de instrumento de ressocialização (ÁVILA; SANTOS, 2017, p. 269). É nessa direção que se enquadra a temática do encarceramento brasileiro, diante de um cenário de invisibilidade, violência e descaso em que estão inseridos os homens e as mulheres presos; a situação nacional revela fragilidades das políticas criminais e sociais no que concerne à redução das desigualdades e ao fortalecimento da cidadania dessas mulheres e suas famílias.

Segundo dados do último diagnóstico de pessoas presas no Brasil, elaborado pelo Departamento de Monitoramento e Fiscalização do Sistema de Execução de Medidas Socioeducativas - DMF -, o cenário é desesperador, o que leva a acreditar que o atual sistema prisional brasileiro parece desconhecer ou desprestigiar os princípios basilares da Constituição. O quadro indica violação do princípio da dignidade da pessoa humana, da proibição da tortura, do tratamento desumano ou degradante e das sanções cruéis, do cumprimento da pena em estabelecimentos distintos, de acordo com a natureza do delito, a idade e sexo do apenado, do respeito à integridade física e moral dos presos, da presunção de não culpabilidade, dos direitos fundamentais à saúde, à educação, à alimentação apropriada e do acesso à Justiça.

O total desrespeito dos direitos fundamentais é revelado de forma inequívoca no retrato brasileiro do cárcere, e esta realidade é consideravelmente intensificada nas prisões de mulheres. As necessidades e experiências femininas devem ser reconhecidas de acordo com o universo feminino e não simplesmente adaptadas aos moldes masculinos (MENDES, 2017, p. 215). Assim, o tema acerca das mulheres encarceradas, objeto de estudo deste trabalho, apresenta diversos problemas e questões delicadas do cárcere feminino, como a situação da maternidade no cárcere, a gravidez, o uso de algemas durante o parto, extensão dos efeitos do cárcere aos filhos, a manutenção de vínculos familiares e afetivos, a efetivação do direito à visita íntima, a concessão de prisão domiciliar diante de instalações improvisadas nos presídios destinados a abrigar mulheres, dentre outros problemas institucionais.

\footnotetext{
4 De acordo com SIQUEIRA (2013, p. 190), incluir-se-ia, ainda, os hábitos alimentares, "os quais compõem a identidade cultural do grupo e necessitam ser protegido para a preservação da dignidade daquelas pessoas".

5 I - construir uma sociedade livre, justa e solidária; III - erradicar a pobreza e a marginalização e reduzir as desigualdades sociais e regionais; IV - promover o bem de todos, sem preconceitos de origem, raça, sexo, cor, idade e quaisquer outras formas de discriminação.
} 
O cenário do encarceramento feminino brasileiro evidencia ausência de tutela do Estado com relação a esse grupo vulnerável da população e o desrespeito com os direitos fundamentais e de personalidade dos apenados com fins de res(socialização). A vulnerabilidade deste grupo de indivíduos reflete a desigualdade existente, a qual deveria ser tratada com a importância devida. É muito importante a discussão sobre a indispensabilidade de uma análise epistemológica feminista para a verdadeira compreensão do grande aprisionamento feminino vivenciado na atualidade. Uma criminologia feminista autônoma, comprometida com a situação de vulnerabilidade das mulheres encarceradas, quando se busca compreender os processos sociais e históricos que contribuem para o encarceramento de determinada parcela das mulheres, e os imperativos da seletividade e do controle social que caracterizam o sistema penal.

\section{DOS DESAFIOS ENFRENTADOS PELO ESTADO NA EFETIVAÇÃO DOS DIREITOS SOCIAIS}

É diante de um cenário de invisibilidade, violência e descaso em que estão inseridos os homens e as mulheres presos, que a situação nacional revela fragilidades das políticas criminais e sociais no que concerne à redução das desigualdades e ao fortalecimento da cidadania dessas mulheres e suas famílias. Ante a essa realidade, pode-se perguntar onde o problema reside e se há carência de leis. São 32 disposições somente no artigo 50 do texto Constitucional, destinadas à proteção, direta ou indireta, das garantias da pessoa privada de liberdade, revelando um compromisso aparente do Estado. Além disso, a Lei de Execução Penal brasileira encampa rol extenso de direitos e deveres do preso, objetivando a humanização do cumprimento da pena.

Ou seja, o Brasil não carece de leis, mas, sim, de ausência de interesse político em envolver uma minoria lamentavelmente invisível aos olhos da sociedade e, especialmente, do Parlamento. As políticas públicas relacionadas ao cárcere não são populares e dificilmente encontram respaldo dos congressistas (ÁVILA; SANTOS, 2017 , p. 274). Além do mais, vivencia-se uma cultura punitiva diante do quadro da violação constante a direitos fundamentais e falência de políticas públicas que definem a mentalidade de grande parte da população. É mais fácil ignorar esses problemas sociais do que reconhecer parcela de culpa da sociedade pela deterioração do tecido social.

A resposta simbólica ao problema da criminalidade concentra-se nos efeitos do delito, deixando de voltar suas propostas para as raízes estruturais (econômicas e sociais) e político-ideológicas da questão (ARGUELLO, 2005, p. 2). Assim, a política de enfrentamento do crime é endereçada àquelas pessoas seletivamente consideradas como "criminosas" pelo controle formal, em vez de atacar a violência estrutural na qual estão inseridas (pobreza, exclusão e desigualdade social). A partir dessa ideologia, o Estado passa a adotar políticas criminais e penitenciárias com o pragmatismo utilitarista que se impôs na legislação penal, aproveitando as demandas simbólicas para maior intervenção do aparato penal. O Estado assume a sua incapacitação seletiva e cria respostas rápidas para anseios e medos da sociedade, por meio do mecanismo mais simples de retórica política, a saber: "a expressão de sentimentos punitivos" (FONSECA, 2012, p. 319).

A Constituição Federal de 1988, no que se refere à proteção dos direitos sociais, traz um avanço em relação às antigas constituições do Brasil. Antigamente os direitos sociais eram tratados dentro do título "Da ordem econômica e social", mas no novo modelo os direitos sociais são tratados como direitos fundamentais. Sarlet (2009), assim como outros autores, concebe a existência de uma dignidade comum a todos os seres humanos, fomentada no respeito e na satisfação de uma série de direitos indispensáveis para a garantia de uma vida digna, o que, consequentemente, justificaria a universalização dos direitos fundamentais (p. 69).

Com grande nitidez, Arango (2005, p. 37) esclarece sobre a fundamentalidade dos direitos sociais:

Según su genus proximum, los derechos sociales fundamentales son derechos fundamentales, es decir, derechos subjetivos con un alto grado de importancia. Pero lo que distingue a los derechos sociales fundamentales de otros derechos fundamentales (differentia specifica) es que son "derechos de prestación en su sentido estrecho", es decir, derechos generales positivos a acciones fácticas del Estado.

Assim, os direitos sociais positivados constituem-se em obrigações positivas, conferindo característica de exigibilidade (KELLER, 2007, p. 232). O estado democrático de direito está conectado de forma indissolúvel à realização dos direitos fundamentais, e é como decorrência dessa prestação positiva que vem a questão da previsão de recursos suficientes ao seu total atendimento. 
O que se constata é uma dificuldade na efetivação dos direitos sociais em razão de problemas de ordem política, social, administrativa e jurídica. A concepção da garantia jurídico-constitucional dos direitos sociais equivale praticamente a um grau zero de garantia (CANOTILHO, 1993, p. 450).

Os motivos para reduzir direitos a uma mera garantia inacessível são, em primeiro lugar, referentes aos custos dos direitos sociais, aderindo rapidamente à construção da dogmática da reserva do possível para traduzir a ideia de que os direitos sociais somente existem quando existir dinheiro nos cofres públicos (CANOTILHO, 1993, p. 451). O grande problema é que a reserva do possível foi pensada para ser um instituto excepcional no nosso ordenamento, porém de exceção virou regra. Temos, na prática, a reserva do possível sendo alegada de maneira indiscriminada.

É exatamente para proteger o cidadão de bem dessa alegação indiscriminada que se começou a utilizar a tese do mínimo existencial, salvaguardando uma esfera última de direitos; direitos estes contra os quais nenhuma tese de insuficiência financeira estatal poderá ser alegada. Diante dessa situação Canotilho (1993, p. 451) leciona no sentido de que "[...] um direito social sob 'reserva dos cofres cheios' equivale, na prática, a nenhuma vinculação jurídica".

Nesse sentido, a impressão que se tem quando se estuda esse assunto é que existe uma máxima que permeia no poder público, na direção de que o orçamento é insuficiente e, de certa forma, realmente o rol de garantias e direitos sociais é extenso e mais custoso que o direito de liberdade, por exemplo.

O óbice orçamentário ou reserva do possível, porém, não passa de mera retórica diante da concepção da garantia jurídica-constitucional (KELLER, 2007, p. 264). Enquanto outros países estão trabalhando para maximizar, o Brasil ainda está brigando pelo mínimo, mesmo sendo um país de carga tributária elevadíssima.

Seria uma metodologia interessante estabelecer critérios objetivos para evitar decisões judiciais tão contraditórias, além da necessidade de se discutir o orçamento público por meio de audiências públicas, utilizando as redes de tecnologia de informação para que, assim, clareie se é efetivamente um problema de restrição orçamentária naquele dado concreto ou é um mero problema de eficiência.

É nessa perspectiva que a sociedade deve agir em parceria com o Estado na reorganização da sociedade. O importante é criar um movimento de solidariedade capaz de envolver a todos, visando a alcançar as mudanças almejadas, inclusive na ordem jurídica (KELLER, 2007, p. 274).

Assim, a inclusão social somente irá efetivamente acontecer por meio da prestação de serviços públicos com a participação efetiva da cidadania e da sociedade civil. É diante do fato de os direitos sociais serem normas de eficácia plena e imediata, impondo obrigação positiva do Estado, que se verifica a importância da compreensão adequada de quem são os destinatários, pois a questão da titularidade dos direitos fundamentais tem íntima ligação com a característica jurídica do sujeito de direitos.

Por esse ângulo, Flavia Piovesan (2004, p. 29) enfatiza que "A efetiva proteção dos direitos humanos demanda não apenas políticas universalistas, mas também específicas, endereçadas a grupos socialmente vulneráveis, enquanto vítimas preferenciais da exclusão". A eficiência dos direitos sociais, portanto, depende diretamente da correta compreensão dos seus destinatários, com suas respectivas peculiaridades, e dos fatores que geram suas vulnerabilidades diante do caso concreto.

No que concerne às mulheres em situação de cárcere, consideradas grupo vulnerável, se exige medidas positivas estatais e da sociedade na promoção dos direitos sociais, que venham a incluir este segmento de pessoas tão invisíveis da sociedade. A mulher presa quer ser incluída na sociedade enquanto pessoa que é, dotada de direitos e dignidade.

\section{DA RESSOCIALIZAÇÃO DA MULHER PRESA E A EFETIVA JUSTIÇA SOCIAL}

Diante da invisibilidade das mulheres inseridas no sistema prisional brasileiro, até mesmo pelos estudos de criminologia, torna-se essencial traçar alguns pontos para explicar como é o perfil dessas pessoas e a regulamentação do atual cenário jurídico brasileiro. 
Inicia-se trazendo dados oficiais de informações estatísticas do sistema penitenciário brasileiro - o Infopen. ${ }^{6}$ As estatísticas demonstram que o número de pessoas presas cresceu $707 \%$ em relação ao total registrado no início da década de 90 (BRASIL, 2017a); já com relação à população carcerária feminina, o aumento exponencial chega a $656 \%$ em relação ao total registrado no início dos anos 2000 , enquanto na masculina o porcentual foi de $293 \%$ no mesmo período (BRASIL, 2017b). O que ainda se denota do levantamento é a assustadora porcentagem de $45 \%$ que se refere à população carcerária feminina presa provisoriamente; um aumento com relação a primeira edição do Infopen mulheres de junho de 2014 , que mostrava $30,1 \%$ nessa condição (BRASIL, 2017b).

Quanto ao perfil das mulheres privadas de liberdade, as estatísticas revelam a vulnerabilidade e exclusão social, tendo em vista que, em sua larga maioria, têm origem em classes populares, com baixa instrução e exclusão do mercado formal de trabalho. Dados elucidam que a maioria das mulheres presas é negra (62\%), jovem (o maior índice de presas está na faixa etária de 18 a 29 anos) e com pouco ou nenhum estudo. Cerca de $66 \%$ da população prisional feminina ainda não acessou o Ensino Médio, tendo concluído, no máximo, o Ensino Fundamental, e apenas 15\% da população prisional feminina concluiu o Ensino Médio (2017b, p. 40).

Sobre a educação da mulher, o Relatório do Desenvolvimento Humano 2013, publicado pelo Programa das Nações Unidas para o Desenvolvimento (PNUD), ${ }^{7}$ enfatiza a importância da educação da mãe no desenvolvimento, e na própria sobrevivência da criança, mais do que o rendimento familiar propriamente dito, o que evidencia a necessidade de realizar políticas públicas destinadas a melhorar a educação de jovens do sexo feminino (PNUD, 2013, p. 6).

A atuação seletiva do sistema de justiça penal ocasiona muitas violações e institui uma forma paradoxal de enfrentar a criminalidade feminina. Os dados atuais mostram que esmagadora maioria dos detentos do sistema penitenciário brasileiro hoje é oriunda da parcela mais vulnerável da população. No caso das mulheres, as pesquisas indicam que a maioria encontra-se no sistema penitenciário em razão de envolvimento com o tráfico de drogas. Cerca de 62\%, ou seja, 3 em cada 5 mulheres do sistema prisional, respondem por crimes ligados ao tráfico (BRASIL, 2017b). Embora o crime de tráfico seja expressivo na comunidade carcerária masculina, existe uma grande diferença quando tal estatística é confrontada com os dados referentes às penitenciárias femininas.

Para compreender como, onde e por que o crime de tráfico ocorre, não são suficientes perguntas epistemologicamente construídas a partir da condição socioeconômica dessa parcela das mulheres. As pesquisas sobre o controle social, como é o caso das mulheres criminalizadas e vitimizadas, precisam ultrapassar uma visão instrumentalista e funcionalista do mesmo, buscando formas multidimensionais de pensar o problema, tendo em vista os complexos mecanismos que produzem comportamentos considerados adequados ou não com relação à determinada norma ou instituição social (ALVAREZ, 2004, p. 175).

Esse não é apenas um retrato do Brasil; caracteriza também o perfil de outros países. Davis e Dent (2003, p. 527), conhecidas internacionalmente por seu engajamento no combate a todas as formas de opressão nos Estados Unidos e em outros países, afirmam que suas visitas às prisões ao redor do mundo, principalmente às prisões femininas, constataram uma importante similaridade no perfil das presas. Segundo ela, essa similitude das prisões femininas precisa ser estudada com relação ao quanto é importante para o feminismo desprender-se da noção de que existe uma qualidade universal que podemos chamar de mulher.

Essa similaridade entre as instituições prisionais, portanto, pode exemplificar um importante indicativo do uso das prisões como instituição historicamente contingente, que denota as intersecções entre sistemas punitivos, econômicos, sexistas e racistas na modernidade nos diversos lugares do mundo (DAVIS; DENT, 2003, p. 527). Assim, estudos sobre as prisões é uma pesquisa sobre a própria sociedade, sobre o poder e mecanismos opressivos que perpetuam práticas de restrições, subordinações e múltiplas privações (CARVALHO; MAYORGA, 2017, p. 102).

\footnotetext{
6 O Infopen é atualizado pelos gestores dos estabelecimentos desde 2004, sintetizando informações sobre os estabelecimentos penais e a população prisional. Disponível em: http://depen.gov.br/DEPEN/depen/sisdepen/infopen. Acesso em: 10 jun. 2018.

O Relatório do Desenvolvimento Humano "A Ascensão do Sul: Progresso Humano num Mundo Diversificado" de 2013, avalia igualdade de gênero, extrema pobreza e desigualdades no Índice de Desenvolvimento Humano, e analisa as questões e tendências emergentes, bem como os novos atores que moldam o panorama do desenvolvimento. Disponível em: http://hdr.undp.org/sites/default/files/hdr13_ summary_pt_web.pdf. Acesso em: 5 jun. 2018.
} 
As mulheres encarceradas estão em situação de vulnerabilidade social, e isso quer dizer que estão em uma situação em que o conjunto de recursos e habilidades inerentes a um dado grupo social se revela insuficiente para lidar com o sistema de oportunidades oferecido pela sociedade. Assim, a prisão opera de modo extremamente funcional ao selecionar a população que se encontra na marginalidade social. $O$ que se visualiza é um sistema penal que se configura como uma instância do controle social, que nada mais é do que uma contínua seleção e reprodução das relações de desigualdade de produção, em conjunto com outras formas de controle social formal e informal (ÁVILA, 2013, p. 206).

A seletividade é a função real e a lógica estrutural de funcionamento do sistema de justiça criminal, comum às sociedades patriarcais e capitalistas. O que mais evidencia essa seletividade é a própria clientela da prisão, ao revelar que a construção simbólica e instrumental da criminalidade incide estigmatizantemente sobre a pobreza e a exclusão social, majoritariamente masculina e residualmente feminina, apesar de nesta última se verificar um crescimento vertiginoso (ANDRADE, 2007, p. 81).

Logo, o sistema de justiça criminal funciona como um mecanismo público integrativo do controle informal dirigido à mulher, reforçando o controle patriarcal, a estrutura e o simbolismo de gênero, ao criminalizar a mulher em algumas situações específicas e, principalmente, por reconduzi-la ao lugar de vítima, ou seja, "mantendo a coisa em seu lugar passivo" (ANDRADE, 2007, p. 89).

Atualmente fala-se muito sobre a feminização da pobreza, ou seja, da consideração estatístico-social de que a pobreza tem atingido de forma significativa as mulheres e orientado suas escolhas de vida. Os fatores socioeconômicos fundamentam a feminização da pobreza e podem ser considerados os aspectos fundamentais para a compreensão do crescente aumento de mulheres no mercado ilícito das drogas e a sua criminalização, enquanto lógica seletiva do sistema penal. O conceito de "feminização da pobreza" foi introduzido por Diane Pearce em 1978 (BUVINIC; GUPTA, 1994, p. 24), e seu pressuposto era o de que a pobreza está rapidamente se tornando um problema feminino, e associa este processo de empobrecimento das mulheres ao aumento na proporção de famílias pobres chefiadas por mulher.

Em síntese, Pearce (1978, p. 35) leciona que a pobreza masculina e a pobreza feminina são problemas diferentes, que requerem soluções diferentes. Para os homens, a questão principal é uma maior carga de dependência (vários estudos indicam que o número de filhos nas famílias nucleares é maior do que nas de chefia feminina). Para as mulheres, a questão principal é o mercado de trabalho. Inicialmente, os estudos sobre feminização da pobreza, seguindo o desenho de Pearce, tomam como foco a renda. Posteriormente, foi introduzida a preocupação com a transmissão intergeracional da pobreza. Segundo Novellino (2004, p. 9),

Nos anos 90, medir a pobreza feminina somente pela renda passa a ser considerado como insuficiente. Começa-se, então, a analisar o consumo domiciliar, comparando-os de duas maneiras diferentes: (a) dentro de cada domicílio, desagregando os dados por sexo (principalmente dos filhos, para verificar diferenças ou preferências); e (b) entre os domicílios de chefia feminina/masculina.

Um aspecto importante é o fato de muitas mulheres formarem famílias monoparentais, não contando, assim, com a corresponsabilidade do pai. Em uma cultura baseada na ética do cuidado como parte da condição feminina, resulta na diretriz de que as mulheres são consideradas as responsáveis diretas pelo cuidado e sustento dos filhos, tornando-se chefes de família (MACEDO, 2008, p. 396), não existindo a cooperação do outro para compor a renda familiar e nem para compartilhar a responsabilidade pelo cuidado dos filhos.

A maior parte das políticas públicas de gênero são de cunho assistencialista e voltadas para a família, assumindo a maternidade como o papel mais importante para as mulheres, e isso é gerador de dependência destas, ou seja, essas políticas públicas não reconhecem as especificidades de gênero relacionadas ao planejamento de políticas para as mulheres, focando sua preocupação em atender às necessidades práticas da mulher relacionadas às funções reprodutivas (NOVELLINO, 2004, p. 11).

As mulheres em situação de cárcere representam uma parcela da sociedade vulnerável, que sofreu sob os ciclos de reprodução de discriminação, exclusão e violência, carecendo, por sua vez, de políticas públicas emergenciais efetivas para o exercício pleno da cidadania. Para melhor compreensão do que seja uma política pública, Maria Paula Dallari Bucci (2006, p. 39) utiliza-se das seguintes palavras: 
Política pública é o programa de ação governamental que resulta de um processo ou conjunto de processos juridicamente regulados - processo eleitoral, processo de planejamento, processo de governo, processo orçamentário, processo legislativo, processo administrativo, processo judicial - visando coordenar os meios à disposição do Estado e as atividades privadas, para a realização de objetivos socialmente relevantes e politicamente determinados. Como tipo ideal, a política pública deve visar a realização de objetivos definidos, expressando a seleção de prioridades, a reserva de meios necessários à sua consecução e o intervalo de tempo em que se espera o atingimento dos resultados.

Com efeito, por intermédio das políticas públicas, o Estado deve garantir a efetividade e o cumprimento dos direitos previstos no ordenamento jurídico, de maneira sistemática e abrangente, seguindo uma prioridade elencada das necessidades. Assim, para que ocorra o rompimento dos padrões de discriminação e desigualdade que relegam as mulheres à exclusão social, é essencial a construção de políticas públicas transversais mentalizadas e aplicadas a partir do referencial feminino.

Desse modo, compreender o aumento do encarceramento feminino por intermédio da perspectiva feminista permitirá o entendimento sobre os imperativos de seletividade e controle que configura o sistema penal, sistema esse que obscurece processos sociais e históricos que contribuem para o encarceramento de certa parcela de mulheres. Para isso, é essencial se construir uma análise histórica das mulheres ante o poder punitivo e o processo de criminalização e vitimização das mulheres sob uma perspectiva de gênero, por meio da compreensão de como historicamente o poder patriarcal e o poder punitivo articularam-se para sua custódia pelo Estado, pela família e na sociedade (MENDES, 2017, p. 14).

Os levantamentos oficiais informam uma situação de grave crise do sistema penitenciário brasileiro, principalmente no que se refere à capacidade de realizar a pretensa ressocialização dos sujeitos apenados e dar a eles melhores condições de retorno social após o período de restrição de liberdade, do que aquela que detinham antes de seu ingresso nesse sistema. Conforme Greco (2011, p. 191), as prisões são "masmorras que ainda resistem ao século XXI, abrigam, como regra, somente um grupo determinado de pessoas, vale dizer, os miseráveis, os abandonados pelo Estado".

Em suma, verifica-se a real importância do processo de reeducação e de reinserção social, e que estes passem obrigatoriamente pelo respeito incondicionado à dignidade humana do preso(a) e à sua personalidade (CERVINI, 1995, p. 46).

Tendo feito brevemente uma contextualização da situação prisional brasileira e do perfil das mulheres em situação de cárcere, se passará à análise com relação à justiça social perante as pessoas consideradas desprovidas de legitimidade, e mesmo de direitos, como as pessoas presas.

\subsection{Da justiça social}

Um dos principais fundadores teóricos sobre o conceito de justiça no debate contemporâneo é John Rawls. Para ele, a justiça é a escolha justa dos princípios que governam a distribuição de bens primários (FRASER, 2001, p. 249). Segundo o teórico, uma sociedade justa é aquela capaz de criar mecanismos, compensatórios e/ou regulatórios, que minimizem as desigualdades econômicas com base em uma noção de equidade.

Assim, para Rawls (2003, p. 249), justiça como equidade é composta de duas partes: “(1) uma interpretação de uma situação inicial e do problema da escolha colocada naquele momento, e (2) um conjunto de princípios que, segundo se procura demonstrar, seriam aceitos consensualmente." Denota-se que o pensamento rawlsiano está voltado para delimitar a deliberação e a cooperação social, de tal modo que o diálogo entre representantes de diferentes grupos ou doutrinas abrangentes razoáveis conduza a decisões que atendam às partes envolvidas, sendo resultado de um acordo que seja equitativo (RAWLS, 2003, p. 22-23).

Não se nega o grande marco representativo que é a teoria de justiça de J. Rawls, porém sua teoria não nos oferece uma diretriz, ou resposta direta, às reivindicações das minorias e/ou grupos vulneráveis; isso porque o teórico propõe uma teoria ideal, traçando as linhas gerais para uma democracia liberal baseada em uma justiça equitativa (SANTOS, 2011, p. 167). 
Com o objetivo de aprofundar sobre a temática da justiça social, traz-se em tela a proposta teórica de Nancy Fraser. A crítica de Fraser (2009, p. 12) consiste na problematização da justiça social como mecanismos que garantam distribuição e reconhecimento, tendo em vista que as fontes de desigualdade podem ser resultado de um acesso desigual dos bens e serviços quanto ao reconhecimento de suas identidades de grupo.

Conforme leciona Fraser (2009), é de essencial importância a organização da sociedade. Em suas palavras:

As pessoas podem ser impedidas da plena participação por estruturas econômicas que thes negam os recursos necessários para interagirem com os demais na condição de pares, neste caso, elas sofrem injustiça distributiva ou má distribuição; por outro lado, as pessoas também podem ser coibidas de interagirem em termos de paridade por hierarquias institucionalizadas de valoração cultural que lhes negam o status necessário; neste caso elas sofrem de desigualdade de status ou falso reconhecimento. [...] Se a representação é a questão definidora do político, então a característica política da injustiça é a falsa representação (p. 21).

Assim, de que maneira pode-se garantir uma efetiva justiça social com relação à parcela da sociedade referente às mulheres em situação de cárcere, ou seja, pessoas desprovidas de legitimidade e mesmo de direitos?

Nega-se a esses indivíduos acesso aos diversos direitos fundamentais, como educação, trabalho e moradia. Isso tudo se dá por meio de uma distribuição desigual da precariedade da vida. Quanto ao direito à educação, são notórios os reflexos diretos que a precariedade da educação brasileira gera em outras áreas, como a da saúde, índices de mortalidade e, principalmente, no sistema carcerário.

Desta maneira, se faz importante ressaltar, sobre a temática de justiça social, a contribuição teórica de Jurgen Habermas (2002), ao discutir que a existência das minorias inatas são invisibilizadas pelo ideal liberal da autodeterminação. Vale mencionar suas palavras:

O problema [das minorias inatas] também surge em sociedades democráticas, quando uma cultura majoritária, no exercício do poder político, impinge às minorias a sua forma de vida, negando assim aos cidadãos de origem cultural diversa uma efetiva igualdade de direitos (p. 170).

É imperioso garantir a legitimidade das minorias, sendo assegurada, por meio do reconhecimento da diversidade, a igualdade política dos cidadãos. Em suma, carreado os aspectos teóricos de justiça social, verifica-se a imprescindibilidade deste reconhecimento e o respeito ao diferente para a garantia da dignidade da pessoa humana.

Impõe-se a necessidade nos órgãos competentes de um trabalho institucional de apoio e assistência às mulheres encarceradas e aos seus familiares, tendo em vista que a sociedade continua presa ao passado, fundindo o presente de experiências fracassadas, sem a devida reinserção da pessoa presa à sociedade.

\subsection{Da ressocialização da mulher presa e os direitos sociais à educação}

O universo interior do sistema prisional é reflexo de uma sociedade que revela suas fissuras em relação à justiça social e distribuição de renda. A baixa escolaridade da população carcerária feminina, verificada pelos dados oficiais anteriormente expostos, nos remete a ponderar sobre o importante papel da educação e qual sua efetividade no processo de ressocialização.

Sobre a ressocialização, Bitencourt (2004, p. 132) professa que:

O conceito de ressocialização deve ser submetido necessariamente a novos debates e a novas definições. É preciso reconhecer que a pena privativa de liberdade é um instrumento, talvez dos mais graves, com que conta o Estado para preservar a vida social de um grupo determinado. Este tipo de pena, contudo, não resolveu o problema da ressocialização do delinqüente: a prisão não ressocializa. As tentativas para eliminar as penas privativas de liberdade continuam. A pretendida ressocialização deve sofrer profunda revisão.

Nesse sentido, de acordo com Santos (2011, p. 45), os indicadores do sistema penitenciário nacional escancara a ineficácia dos argumentos de reintegração social contraditoriamente ao seu papel segregador e vulnerabilizador de determinadas parcelas da sociedade; ocorre, assim, um verdadeiro processo de criminalização da pobreza. 


\section{Direito自

Referente aos danos que as instituições prisionais podem causar na vida de quem a elas são submetidas, Roberta da Silva (1997, p. 176) aduz que "[...] os efeitos mais duradouros de processo de institucionalização são os danos à constituição da identidade, a afirmação do 'estigma', a incorporação do sentimento de inferioridade e a redução significativa da autoestima".

Esses efeitos danosos do sistema são intensificados no que diz respeito ao universo feminino no contexto de reintegração social, uma vez que o processo de estigmatização se exacerba quando somado ao sexismo vivenciado por estas em suas relações sociais rotineiras. Assim, o processo de ressocialização deve necessariamente abarcar os aspectos que envolvem a construção da imagem da mulher, o papel da educação, do trabaIho e da qualificação no cárcere.

É nesse contexto que se visualiza a importância do direito à educação e suas consequências no plano jurídico e social. $\mathrm{O}$ artigo 60 da Constituição Brasileira explicitamente elenca a educação como direito no capítulo destinado ao rol de direitos sociais. Compõe-se em verdadeira clausula pétrea e, nesse diapasão, encontra-se protegido pelo disposto no artigo 60 § 4ํ, inciso IV, da Constituição de 1988.

Aliás, como alerta Motauri Ciocchetti de Souza (2010):

[...] a igualdade de oportunidades e a asseguração do mínimo existencial somente poderão surgir se a todos for assegurado o direito a processo educacional adequado. Nessa quadra, difere a educação de outros direitos sociais e fraternos, igualmente consagrados pela Magna Carta: a educação é premissa - e não proposta.

O Relatório do Desenvolvimento Humano de 2013, publicado pelo Programa das Nações Unidas para o Desenvolvimento (PNUD), ${ }^{8}$ enfatiza a importância da educação da mãe no desenvolvimento, e na própria sobrevivência da criança, mais do que o rendimento familiar propriamente dito, o que evidencia a necessidade de realizar políticas públicas destinadas a melhorar a educação de jovens do sexo feminino (PNUD, 2013, p. 6).

Segundo dados trazidos por Cunha (2010, p. 170) de sua pesquisa de Doutorado sobre o Centro de Ressocialização Feminino (CRF) de Araraquara, a realidade educacional das mulheres que cumprem pena no CRF reflete a situação das demais instituições prisionais brasileiras. Segundo a autora, na Fundação de Amparo ao Trabalhador Preso, em novembro de 2005, "[...] 47,53\% da população carcerária trabalhavam e 17,02\% estudavam, em dezembro do mesmo ano, cerca de $78 \%$ da população masculina e $69 \%$ da população feminina eram analfabetas ou possuíam ensino fundamental incompleto".

Conforme aduz Baratta (2002), há um fator social que se relaciona às chances de alguém ser selecionado como criminoso e preso, reiterando e perpetuando desigualdades e exclusões já presentes antes do encarceramento. Segundo suas palavras, a criminalidade se revela com:

[...] um status atribuído a determinados indivíduos, mediante uma dupla seleção: em primeiro lugar, a seleção dos bens protegidos penalmente, e dos comportamentos ofensivos destes bens, descritos nos tipos penais; em segundo lugar, a seleção dos indivíduos estigmatizados entre todos os indivíduos que realizam infrações a normas penalmente sancionadas (p. 161).

Vale enfatizar que, no caso das mulheres em situação de cárcere, há uma dupla violação, uma dupla criminalização, a ideia que faz referência à criminalização normal a quem comete um delito, mas também a uma "criminalização sem tipo penal" (CASTILHO, 2008, p. 121), aquela que reflete a reprovação social originada de um preconceito de gênero, cabendo, ainda, um extra de sofrimento na prisão pelo fato de ser mulher porque há sempre o outro, do lado de fora, que a cobra, fere, abandona, estigmatiza e culpabiliza, não somente pelo delito, mas pela violação do papel social. Esse outro é nada mais nada menos que nós, todos nós, quando desprovidos de empatia pelo sofrimento delas e de tantas outras.

\footnotetext{
8 O Relatório do Desenvolvimento Humano "A Ascensão do Sul: Progresso Humano num Mundo Diversificado" de 2013, avalia igualdade de gênero, extrema pobreza e desigualdades no Índice de Desenvolvimento Humano, e analisa as questões e tendências emergentes, bem como os novos atores que moldam o panorama do desenvolvimento. Disponível em: http://hdr.undp.org/sites/default/files/hdr13_ summary_pt_web.pdf. Acesso em: 5 jun. 2018.
} 
Os estigmas operam como uma marca socialmente construída em relação às pessoas presas e abrem pouca possibilidade à mudança, posto que reforçam o que é negativo e o que se espera destas em suas relações sociais e até na possível influência em relação ao seu entorno. Conforme Goffman (1975, p. 57), “[...] uma pessoa com ordem de prisão pode contaminar legalmente qualquer um que seja visto em sua companhia, expondo-o à prisão como suspeito".

O acesso ao direito à educação é um fator que pode promover a proteção e a redução de vulnerabilidades sociais no retorno à vida em sociedade, marcada por disputas e desigualdades na busca e direito por trabalho e renda. No contexto da prisão, a adesão das pessoas privadas de liberdade às atividades educacionais, notadamente as escolares, ainda é muito relacionada à ocupação do tempo livre ou à redução de parte da pena, por meio da remição. Infelizmente, ela não se encontra relacionada ao exercício de um direito ou ao acesso ao conhecimento e aumento da escolaridade

Evidencia-se que o direito à educação carrega em si as características dos direitos fundamentais, ou seja, não se sujeita à vontade do legislador ou à boa vontade do Estado. Surge, assim, o dever de atuar positivamente, seja criando condições normativas adequadas ao exercício do direito, seja na criação de condições reais, como estruturas, instituições e recursos humanos, principalmente dentro do regime prisional, tendo em vista a realidade carente da população carcerária. A escolarização dentro da prisão tem como finalidade a formação das presas nos Ensinos Fundamental e Médio e sua ressocialização do ponto de vista moral, ético e social. O aumento do nível escolar é imprescindível para que as mulheres presas consigam melhores oportunidades de trabalho e inserção social após o período de cárcere.

\section{CONSIDERAÇÕES FINAIS}

O problema do presente estudo consistia em dar visibilidade a uma parcela da sociedade muito estigmatizada, esquecida e em situação de extrema vulnerabilidade: as mulheres encarceradas pelo sistema prisional brasileiro. Buscou-se, assim, ir além dos muros penitenciários para se compreender o aprisionamento feminino, tendo em vista que a grande parte das mulheres em situação de cárcere vive em um cenário de descaso.

Procurou-se, portanto, traçar o perfil das mulheres presas, como vivem e quais são as maiores deficiências deste grupo de vulneráveis. Comprovou-se que a eficiência dos direitos sociais depende umbilicalmente da correta compreensão dos seus destinatários, com suas respectivas peculiaridades, e dos fatores que geram suas vulnerabilidades. Assim, o estudo quedou-se claro que é por intermédio das políticas públicas que o Estado deve garantir a efetividade e cumprimento dos direitos essenciais dessa parcela da população, seguindo uma prioridade elencada das necessidades.

Nesta oportunidade, para que ocorra o rompimento dos padrões de descriminação e desigualdade que relegam as mulheres à exclusão social, se verificou ser essencial a construção de políticas públicas transversais mentalizadas e aplicadas a partir do referencial feminino, tendo em vista que as ações institucionais se desenvolvem sem mero planejamento, não trazendo em consideração a humanização da execução penal, principalmente referente à falta de perspectiva de uma verdadeira ressocialização por meio da educação e de oportunidades de ingressar no mercado de trabalho, levando à reincidência nas práticas delituosas, principalmente no mercado das drogas.

Concluiu-se que, apesar da existência de uma Constituição garantidora de direitos e aderência em pactos humanos internacionais, não há correspondência entre o expresso nos instrumentos legais e normativos e a realidade que vivencia a mulher encarcerada, revelando a necessidade de estabelecimento de políticas públicas específicas para a realidade prisional feminina, tendo a educação como premissa para a real justiça social.

\section{REFERÊNCIAS}

ABRAMOVAY, Miriam et al. Juventude, violência e vulnerabilidade social na América Latina: desafios para políticas públicas. Brasília: Unesco; BID. 2002.

ALEXY, Robert. Teoría de los derechos fundamentales. Madrid: Centro de Estudios Constitucionales, 1993.

ALVAREZ, Marcos César. Controle social: notas em torno de uma noção polêmica. São Paulo Perspec, v. 18, n. 1, mar. 2004. Disponível em: http://www.scielo.br/scielo.php?script=sci_arttext\&pid=S010288392004000100020\%Ing=en\&nrm=iso. Acesso em: 10 jun. 2019.

ANDRADE, Vera Regina Pereira. A soberania patriarcal: o sistema de justiça criminal no tratamento da violência sexual contra mulher. Revista de Direito Público, n. 17, jul.-set./2007. 


\section{Debate}

ANJOS FILHO, Robério Nunes dos. Minorias e grupos vulneráveis: uma proposta de distinção. In: ANJOS FILHO, Robério Nunes dos; BOITEUX, Elza Antonia Pereira Cunha (org.). Direitos humanos: estudos em homenagem ao professor Fábio Konder Comparato. Salvador: Juspodivm, 2010. p. 405-432. V. 1.

ARANGO, Rodolfo. El concepto de derechos sociales fundamentales. Buenos Aires: Legis, 2005.

ARGÜELLO, Katie. Do Estado social ao Estado penal: invertendo o discurso da ordem. 10 Congresso Paranaense de Criminologia: Londrina, 2005. Disponível em: http://icpc.org.br/wp-content/uploads/2013/01/Artigo-Katie.pdf. Acesso em: 10 jun. 2019. ÁVILA, Gustavo Noronha de. Falsas memórias e sistema penal: a prova testemunhal em xeque. Rio de Janeiro: Lúmen Juris, 2013. ÁVILA, Gustavo Noronha; SANTOS, Marcel Ferreira. Encarceramento em massa e estado de exceção: o julgamento da Ação de Descumprimento de Preceito Fundamental 347. Revista Brasileira de Ciências Criminais, v. 136, p. $267-291,2017$.

BARATTA, Alessandro. Criminologia crítica e crítica do Direito Penal: introdução à Sociologia do Direito Penal. 3. ed. Rio de Janeiro: Editora Revan; Instituto Carioca de Criminologia, 2002.

BARROSO, Luís Roberto. A dignidade da pessoa humana no Direito Constitucional Contemporâneo: a construção de um conceito jurídico à luz da jurisprudência mundial. Belo Horizonte: Fórum, 2013.

BITENCOURT, Cezar Roberto. Falência da pena de prisão. São Paulo: Saraiva, 2004.

BONAVIDES, Paulo. Teoria constitucional da democracia participativa: por um Direito constitucional de luta e resistência, por uma nova hermenêutica, por uma repolitização da legitimidade. São Paulo: Malheiros Editores, 2001.

BRASIL. Constituição da República Federativa do Brasil. Disponível em: http://www.planalto.gov.br/ccivil_03/constituicao/ constituicaocompilado.htm. Acesso em: 4 jun. 2018.

BRASIL. Ministério da Justiça. Levantamento nacional de informações penitenciárias - Infopen. Brasília, DF, 2017a. Disponível em: http://depen.gov.br/DEPEN/depen/sisdepen/infopen/relatorio_2016_22-11.pdf. Acesso em: 5 jun. 2018.

BRASIL. Ministério da Justiça. Departamento Penitenciário Nacional. Diretrizes para a convivência mãe-filho/a no sistema prisional. 2016. Disponível em: www.justiça.gov.br/seus-direitos/politica-penal/politicas-2/mulheres-1/normativos. Acesso em: 6 jun. 2018.

BRASIL. Ministério da Justiça. Levantamento Nacional de Informações Penitenciárias - Infopen Mulheres. Brasília, DF, 2017b. Disponível em: http://depen.gov.br/DEPEN/depen/sisdepen/infopen-mulheres/infopenmulheres_arte_07-03-18.pdf. Acesso em: 5 jun. 2018.

BUCCI, Maria Paula Dallari. O conceito de política pública em direito. In: BUCCI, Maria Paula Dallari (org.). Políticas públicas: reflexões sobre o conceito jurídico. São Paulo: Saraiva, 2006.

BUVINIC, M.; GUPTA, G. R. Targeting poor woman-headed households and womenmaintained families in developing countries: views on a policy dilemma. Washington, DC: International Center for Research on Women and the Population Council, 1994.

CANOTILHO, José Joaquim Gomes. Direito constitucional. 6. ed. rev. Coimbra: Livraria Almedina Coimbra, 1993.

CANOTILHO, José Joaquim Gomes; MOREIRA, Vital. Constituição da República portuguesa anotada. São Paulo: Editora Revista dos Tribunais, 2007.

CARBONELL, Miguel. Estudio Preliminar. La Igualdad y los Derechos Humanos. In: CARBONELL, Miguel (coord.). El Princípio Constitucional de Igualdad: Lecturas de Introducción. México, D.F.: Comisión Nacional de los Derechos Humanos, 2003.

CARVALHO, Daniela Tiffany Prado; MAYORGA, Claudia. Contribuições feministas para os estudos acerca do aprisionamento de mulheres. Revista de Estudos Feministas, Florianópolis, v. 25, n. 1, p. 99-116, abr. 2017. Disponível em: http://www.scielo.br/ scielo.php?script=sci_arttext\&pid=S0104-026X2017000100099\&Ing=en\&nrm=iso. Acesso em: 10 jun. 2019.

CASTILHO, Ela Wiecko Vollmer de. A criminalização do tráfico de mulheres: proteção das mulheres ou reforço da violência de gênero. Cadernos Pagu, n. 31, p. 101-123, jul./dez. 2008.

CASTRO, Mary Garcia et al. Juventude, violência e vulnerabilidade social na América Latina: desafios para políticas públicas. Brasília: Unesco; BID, 2002. Disponível em: http://unesdoc.unesco.org/images/0012/001271/127138por.pdf. Acesso em: 10 jun. 2018. CAYRES, G. R. M.; CIDADE, R. B. As minorias, a condição de vulnerável e ações afirmativas. In: FERRAZ, Anna Candida da Cunha; VITA, Jonathan Barros; SILVEIRA, Helena Colodetti Gonçalves (org.). Direitos e garantias fundamentais II. 1. ed. Florianópolis: Conpedi, 2015. p. 162-181.

CERVINI, Raúl. Os processos de descriminalização. São Paulo: RT, 1995.

COMPARATO, Fabio Konder. A afirmação histórica dos direitos humanos. 4. ed. São Paulo: Saraiva, 2014.

CUNHA, Elizangela Lelis da. Ressocialização: o desafio da educação no sistema prisional feminino. Cad. Cedes, Campinas, v. 30, n. 81 , p. 157-178, ago. 2010. Disponível em: http://www.scielo.br/scielo.php?script=sci_arttext\&pi$\mathrm{d}=\mathrm{S} 010132622010000200003 \&$ Ing=en\&nrm=iso. Acesso em: 15 jun. 2018.

DAVIS, Angela; DENT, Gina. A prisão como fronteira: uma conversa sobre gênero, globalização e punição. Revista Estudos Feministas, Florianópolis, v. 11, n. 2, 2003. Disponível em: http://www.scielo.br/scielo.php?script=sci_arttext\&pi$d=S 0104026 X 2003000200011 \&$ Ing=pt\&nrm=iso\&tlng=pt. Acesso em: 10 jun. 2019.

FONSECA, David S. Assumindo riscos: a importação de estratégias de punição e controle social no Brasil. In: CÂNEDO, Carlos; FONSECA, David F. (org.). Ambivalência, contradição e volatilidade no sistema penal: leituras contemporâneas da sociologia da punição. Belo Horizonte: UFMG, 2012.

FRASER, Nancy. Reenquadrando a justiça em um mundo globalizado. Lua Nova, São Paulo, v. 77, p. 11-39, 2/2009. 
FRASER, Nancy. Da redistribuição ao reconhecimento? Dilemas da justiça numa era pós-socialista. In: SOUZA, Jessé (org.). Democracia hoje: novos desafios para a teoria democrática contemporânea. Brasília: Editora UnB, 2001.

GOFFMAN, Erving. Estigma: notas sobre a manipulação da identidade deteriorada. Rio de Janeiro: Zahar Editores, 1975.

GRECO, Rogério. Direitos humanos, sistema prisional e alternativas à provação de liberdade. São Paulo: Saraiva, 2011.

HABERMAS, Jurgen. Inserção - inclusão ou confinamento? In: HABERMAS, Jurgen. A inclusão do outro: estudos de teoria política. São Paulo: Edições Loyola, 2002.

KELLER, Arno Arnoldo. A exegibilidade dos direitos fundamentais sociais no Estado democrático de direito. Porto Alegre: Sergio Antonio Fabris, 2007.

LOPES, Ana Maria D’Ávila. Multiculturalismo, minorias e ações afirmativas: promovendo a participação política das mulheres. Revista Pensar, Fortaleza: Universidade de Fortaleza, v. 11, fev. 2006.

MACEDO, Márcia dos Santos. Mulheres chefes de família e a perspectiva de gênero: trajetória de um tema e a crítica sobre a feminização da pobreza. Caderno CRH, v. 21, n. 53, p. 385-399, ago. 2008. Disponível em: http://www.scielo.br/scielo.php?pi$\mathrm{d}=$ S0103-49792008000200013\&script=sci_arttext. Acesso em: 12 jun. 2019.

MACHADO, Robson Aparecido. A realidade do egresso: plano normativo da lei de execução penal versus reintegração social. Revista Direitos Sociais e Políticas Públicas, Unifafibe, v. 3, n. 1, 2015.

MENDES, S. R. Criminologia feminista: novos paradigmas. 2. ed. 2. ed. São Paulo: Saraiva, 2017. p. 215.

NAÇÕES UNIDAS. Os Direitos das minorias. Tradução Gabinete de Documentação e Direito Comparado. Ficha informativa n. 18. Lisboa, out. 2008. Disponível em: http://www.gddc.pt/direitos-humanos/Ficha_18.pdf. Acesso em: 10 jun. 2018.

NOVELLINO, Maria Salet Ferreira. Os estudos sobre feminização da pobreza e políticas públicas para mulheres. ENCONTRO DA ABEP, 14., 2004. Disponível em: https://www.google.com/search?q=2017a+2017b\&oq=2017a+2017b\&aqs=chrome..69i57j0l3.5611j0j4\&sourceid=chrome\&ie=UTF-8. Acesso em: 12 fev. 2019.

PEARCE, Diane. The feminization of poverty: women, work and welfare. Urban and Social Change Review, v. 11, p. $28-36,1978$. PIOVESAN, Flávia. Direitos humanos e o direito constitucional internacional. 14. ed. São Paulo: Saraiva, 2013.

PIOVESAN, Flávia. Direitos sociais econômicos e culturais e direitos civis e políticos. Revista Internacional de Direitos Humanos. São Paulo: Human Rights University Network - SUR, ano 1, n. 1, p. 21-47, 2004.

PNUD. Programa das Nações Unidas para o Desenvolvimento. Relatório do Desenvolvimento

Humano 2013. A Ascensão do Sul: Progresso Humano num Mundo Diversificado. 2013. Disponível em: http://www.br.undp.org/ content/brazil/pt/home/library/idh/relatorios-de-desenvolvimento-humano/relatorio-do-desenvolvimento-humano-200012.html. RAWLS, John. Justiça como equidade: uma reformulação. Tradução Cláudia Berlirner. São Paulo: M. Fontes. 2003.

RAWLS, John. Uma teoria da justiça. São Paulo: Martins Fontes, 2002.

REZEC NETO, C.; BORCAT, J. C. Direito fundamental da igualdade: hipótese de atuação material da dignidade da pessoa humana. In: SIQUEIRA, Dirceu Pereira; AMARAL Sérgio Tibiriça do (org.). Democracia, liberdade e justiça social: fundamentos para uma teoria jurídica do reconhecimento? 1. ed. Birigui: Boreal, 2015. V. 1.

ROCHA, Cármen Lúcia Antunes. Ação afirmativa: o conteúdo democrático do princípio da igualdade jurídica. Revista Trimestral de Direito Público, Brasília, 1996. Disponível em: http://www2.senado.leg.br/bdsf/handle/id/176462. Acesso em: 10 jun. 2018. ROTHENBURG, Walter Claudius. Igualdade material e discriminação positiva: o princípio da isonomia. Novos Estudos jurídicos, Itajaí: Univali, v. 13, n. 2, p. 77-92, jul./dez. 2008.

SANTOS, Boaventura de Sousa. Introdução: para ampliar o cânone do reconhecimento, da diferença e da igualdade. In: Reconhecer para libertar: os caminhos do cosmopolitanismo multicultural. Rio de Janeiro: Civilização Brasileira, 2003.

SANTOS, C. A. Há um lugar para as reivindicações das minorias na sociedade Rawlsiana. Ítaca (UFRJ) , v. 16, p. 152-169, 2011.

SANTOS, Raquel Costa de Souza. Maternidade no cárcere: reflexões sobre o sistema penitenciário feminino. 2011. Dissertação (Mestrado) - Universidade Federal Fluminense, Niterói, 2011. Disponível em: https://www.teses.usp.br/teses/disponiveis/5/5170/tde-11052017-140243/publico/PriscillaFeresSpinola.pdf. Acesso em: 12 jun. 2019

SARLET, Ingo Wolfgang. Dignidade da pessoa humana e direitos fundamentais na Constituição Federal de 1988. 7. ed. Porto Alegre: Livraria do Advogado, 2009.

SARLET, Ingo Wolfgang. Igualdade como direito fundamental na Constituição Federal de 1988: aspectos gerais e algumas aproximações ao caso das pessoas com deficiência. In: FERRAZ, Carolina Valença; LEITE, George Salomão; LEITE, Glauber Salomão; LEITE, Glauco Salomão (coord.). Manual dos direitos da pessoa com deficiência. São Paulo: Saraiva, 2012.

SILVA, R. Os filhos do governo. São Paulo: Ática, 1997. (Fundamentos, 137).

SIQUEIRA, Dirceu Pereira; MINHOTO, Antonio Celso Baeta. Igualdade, minorias e legitimidade. In: SANTOS, Murilo Angeli Dias dos (org.). Estudos contemporâneos de Hermenêutica. Birigui: Editora Boreal, 2012.

SIQUEIRA, Dirceu Pereira. A dimensão cultural do direito fundamental à alimentação. Biguiri: Boreal, 2013.

SIQUEIRA, Dirceu Pereira; CASTRO, Lorenna Roberta Barbosa. Minorias e grupos vulneráveis: a questão terminológica como fator preponderante para uma real inclusão social. Revista Direitos Sociais e Políticas Públicas, Unifafibe, v. 5, n. 1, 2017.

SOUZA, Motauri Ciocchetti de. Direito da Educação. In: NUNES JÚNIOR, Vidal Serrano (coord.). Manual de direitos difusos. São Paulo: Verbatim, 2010.

ZAGREBELSKY, Gustavo. El derecho dúctil. Madrid: Editorial Trotta, 2005. 